\title{
THE IMPACT OF BRAND TRUST TOWARD LOYALITY CUSTOMER PERTALITE IN DEPO PERTAMINA MOJOKERTO
}

\author{
Tri Tjahjo Poernomo ${ }^{1}$ \\ Economics and Business Faculty \\ Wijaya Kusuma University \\ purnomotricahyo@gmail.com
}

\begin{abstract}
A R T I C L E I N F O
Article history:

Received: 18 November 2020

Revised: 26 November 2020

Accepted: 3 December 2020
\end{abstract}

Key words:

Accidental samping, brand trust, loyality

DOI: https://doi.org/10.33508/rima.v3i2.3051

\begin{abstract}
A B S T R A C T
This study aims to analyze the effect of the viability (dov) and imtentonality (doi) dimensions on customer loyalty. The research sample consisted of 43 permanent pertalite participants who made repeat purchases at DEPO PERTAMINA Prajurit Kulon, Mojokerto, through the accidental sampling method approach (Cooper \& Emory, 1995). It is concluded that $\mathrm{H1}$ of research: the truth is accepted, $\mathrm{H} 2$ of research: the truth is accepted. Where loyalty is a manifestation of the moral it is positive shown by consumers to their retailers, in line with the opinion (Autry et al. 2007). The research model is quite accurate in predicting the linear influence of brand trust (dov $\mathcal{E}$ doi) on customer loyalty, representing 43 permanent participants who made intention purchases.
\end{abstract}

\section{INTRODUCTION}

Brand Trust provides evidence that it has a significant influence on customer loyalty, meaning that if a branded item is trusted, consumers will tend to repurchase the brand compared to other brands. This has immediate relevance to the formation of customer loyalty values to believe in a brand's existence. Brand Trust is a form of interaction and communication process between brands and customers, followed by marketers.

(Chaudhuri \& Holbrook, 2001) defines that trust in a brand is the average consumer's desire to depend on a brand's ability in all its functions. The emergence of product diversity in one category on product quality that has become standardized and can be easily duplicated or owned by anyone will also impact a business corporation's difficulty to maintain itself as a market leader. To solve the penetration carried out by competitors, the business corporation will strive to maintain its market segmentation by forming a strong brand image by a business corporation.

Without a healthy and positive brand image, business corporations can't attract new customers' interest and maintain something that already exists (Ismani, 2008). According to (Kustini 2001), brand trust can be indicated through satisfaction or value, 1 . The dimension of Viability. and 2. The measurement of Intentionality. This dimension describes the sense of security of an individual against the existence of a brand. This dimension can be measured through security and trust indicators.

From the above explanation, it can be concluded that brand trust is the willingness of consumers to trust a brand with all its consequences because of the expectation that the brand will make a positive contribution to consumers to impact loyalty to the existence of a brand. It can be concluded that brand trust is the feeling of consumers in trusting a brand. Consumers have trusted the product through a product quality process that can 
be remembered in consumers' minds. A consumer will tend to choose the product so that consumers will not switch to other products. Trust in the brand is considered the most critical effort to form and maintain good relationships with customers in the long term.

This implies that the initial creation of a relationship with a business partner is based on trust. Business corporations must understand three essential characteristics in building and developing brand trust, as a determinant of customer trust, leading to customer loyalty. The three critical attributes for successful interactions between customers and business corporations are brand characteristics, corporate business characteristics, and brand-customer interaction characteristics.

Therefore, the trust that has been formed by customers towards a brand is likely to refer to the brand's loyalty. Trust in a brand will impact a consumer's repurchase interest in a product's existence will be even more significant because trust is the beginning of allegiance to a brand. The public or consumers are considered influential parties because they will make purchases of business corporations' products.

The main problem in this research article explains that consumer trust in a brand is crucial because, through confidence in a brand, consumers will be sure of the value they will receive and feel suitable for the products that have been used. Then these consumers will recommend to their friends that these products are highly recommended. This continuation will indirectly affect business corporations because, without spending on brand marketing costs, the wider community will not know its effects. Consumer loyalty is often indicated to be a fundamental concept in understanding retailers' interactions with their consumers. This is because, in essence, commitment is a positive moral manifestation that is shown by consumers to their retailers (Autry et al. 2007).
So it could explain the formulation of the research problem: does brand trust (dov\&doi) have the implications of a positive influence on customer loyalty.This has immediate relevance to the research objectives to conduct an empirical study of the extent to which brand trust influences customer loyalty, as is the conceptual support of marketing theory proposed by (Autry et al. 2007).

\section{THEORICAL BASIS}

\section{Brand Trust}

(Lau \& Lee, 1999), perceives that brand trust is the willingness of customers to lean on a brand and the consequences it faces, because of their expectations for the brand, will have an impact on positive results. It is also interpreted by (Delgado \&Munuera, 2005) that belief in a brand is a brand's ability to be believed (brand reliability). This is rooted in consumer confidence that the product can fulfill the promised value and a brand intention based on the belief consumers that the brand is a belief through evidence that the brand has a practical matter and usability for its users. The three main pillars of brand belief:

1. Brand grouping has a fundamental articulation in determining consumer decision making to trust a brand. This is because consumers assess before making a purchase. The characteristics of a brand that are near related to brand belief include: being predictable, reputable, and competent.

2. A review of the business paradigm written on a brand can also articulate the consumer confidence rating for that brand. Consumer knowledge about the business corporation that is behind the brand of a product is the initial basis for understanding consumer behavior towards a product's brand. These characteristics include the reputation of a business corporation, the business corporation's expected motivation, and the integrity of a business corporation. 
3. Grouping of consumers where the brand consists of 2 groups that influence each other. Therefore, the consumer characteristics of a brand can influence brand belief. This group's conditioning activities include duplication of consumers' emotional conceptualism of brand personality, liking for brands, and brand experiences. Self-concept is the totality of an individual's ideas and feelings by referring to himself as an object. Often, in the context of marketing, the same brand is analogous to people. A brand can have an impression or a personality. Brand personalization is a group of associations with brand attachments that consumers can remember which consumers can accept. Consumers often interact with brands as if they were human. Thus, the similarity of individual consumer conceptualism to brand personality is closely related to consumer confidence. Likeness for brands shows the liking that one group has for another group due to similar visions and visual appeal to initiate a group interaction that must be liked or sympathized with other groups. For consumers to open the business with a brand, consumers must first like the brand's existence. Trust in a brand is considered the most critical method in shaping and maintaining customer interactions over a long period.

This explains that the initial creation of interactions with partners is based on trust. Business corporations must understand three essential characteristics informing and developing a brand trust as a determinant of customer confidence, ultimately referring to customer loyalty. These three characteristics are critical to successful interactions between customers and business corporations. Therefore, the belief that has been formed by customers towards a brand can lead to loyalty to that brand.

\section{Customer Loyalty}

(Kotler et al. 2009) provide an opinion that loyalty is the actualization of deeply held beliefs to carry out purchasing activities or return support for preferred products or services in the future even though the influence of the situation and marketing efforts have the potential to cause customers to switch.

(Oliver, 2010) perceives that loyalty is the actualization of customers' selfconfidence for deep survival to re-subscribe or to repurchase selected products or services consistently in the future. Although the influence of circumstances and marketing efforts have the potential to result in a behavior change.

Opinion (Kotler et al. 2012) that customer loyalty is a situation where customers repeatedly spend all their purchasing power to purchase a service product from a similar seller. Consumer loyalty occurs in several classifications.

According to (Oliver 2010), the classification is as follows: 1. Cognitive loyalty (cognitive loyalty) or loyalty based solely on brand beliefs. 2. Affective dedication or desire or actualization of brand behavior is based on the opportunity to use cumulative satisfaction. 3 . Conative loyalty shows a condition of belief which contains whether at first appearance it can deliver a deep commitment to making a purchase. 4. Action loyalty, where the intention is converted to action.

Grifin (2010) proposes four categories of loyal customers, namely: 1 . Make regular repeat purchases; 2. Buy outside the product or service line (assets across product and service lines), 3. Give confidence outside Product line (Refreshing Other), 4. I am showing the toughness of the essential charisma of similar products from competitors (demonstrates an immunity to the full of the competition).

The benchmark for a business corporation's success to make consumers satisfied is consumer loyalty (Turkyilmaz\&Ozkan, 2007). The shift of consumers from one retail to another can also be a symptom of low consumer loyalty. 
Consumer loyalty is a gold mine for retailers.

(Drezner, 2006) reminiscent of the importance of consumer loyalty as a source of income for retailers. In addition to paying that can undoubtedly go to retail cash, the dedication will also produce a consumer behavior pattern, both short and long term.

(Beriain et al., 2009; Yim et al., 2013). Loyalty is the consumer's self-actualization to the retailer. Consumer loyalty is often indicated to be a fundamental concept in understanding retailers' interactions with their consumers.

In essence, this is because loyalty is a positive moral manifestation that is shown by consumers to their retailers (Autry et al. 2007). Then the elements used to visualize the constructs of consumer loyalty refer to studies (Birgelen et al. 2006); (Boyer et al. 2007); (Diminitriades, 2006), namely recommending other parties, continuing to spend there, and making a family retailer, and not moving to other retailers and talking about good things.

\section{Previous Research}

(Ferdian, 2011) has researched the Analysis of Factors Affecting Consumer Loyalty in the Blessing Supermarkets in BangsiriJepara. Using a sampling of 125 respondents of Swalayan Berkah Bangsri Jepara utilizing the approach (Quota sampling method and purposive sampling). The research's final implication is that $\mathrm{H} 1$ : accepted, H2: accepted, H3: accepted, H4: accepted.

Umar (2014) has researched the factors that influence customer loyalty on low-cost carrier flights. The research sampling consisted of 300 respondents using low-cost carrier flights from January to February 2014 at Soekarno-Hatta International Airport through a stratified random sampling approach. The research's final implication is that H1: accepted, H2: taken, H3: accepted, H4: accepted, H5: accepted, H6: accepted, H7: accepted, H8: accepted, H9: accepted, H10: accepted.

Batubara \&Kharisma (2016) have researched Indi Home Brand Trust's influence on Customer Loyalty in Bandung, using a research sampling of 100 respondents of Indi Home users in the city of Bandung (Accidental Sampling). The research implication of the final research explains that $\mathrm{H} 1$ : accepted, $\mathrm{H} 2$ : taken.

Hypothesis and Analysis Model

H1: Dimension of viability has a positive effect on customer loyalty

H2: Dimension of intentionality harms customer loyalty

Picture 1

Model Analisis

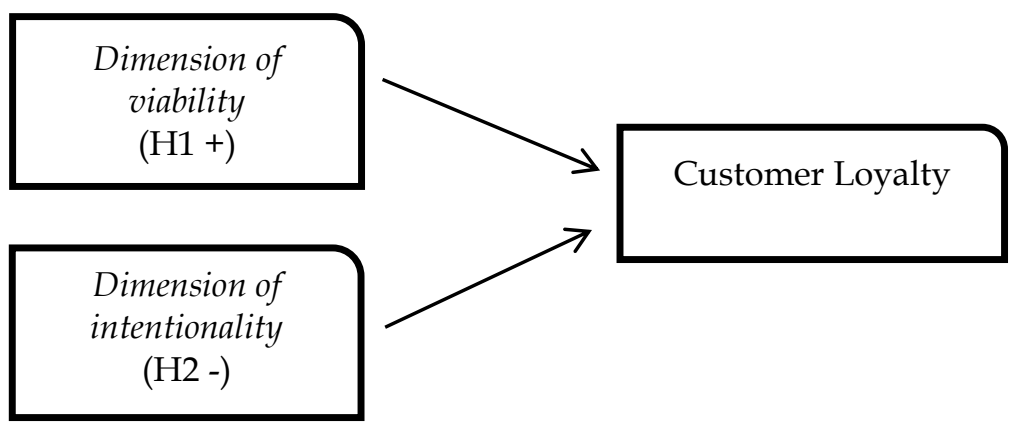

\section{RESEARCH METHODS}

Population and Research Sample

The population in this study, is all consumers who make purchases of pertalite at Depo Pertamina Prasatria Kulon, Mojokerto.

The research sample consisted of 43 permanent pertalite participants who made repeat purchases at the Pertamina Pra 
Soldier Kulon Depot, Mojokerto, through the accidental sampling method approach (Cooper \& Emory, 1995). With Criteria:

1. Age and Gender (free)

2. Permanent customer of pertalite gasoline at the Pertamina depot, PrasatriaKulon

3. Did not move to another Pertamina depot outside of Praetor Kulon for the next month

4. Customers fully believe that the purchased pertalite fuel (not lead content) can damage motorized vehicle engines

\section{$\underline{\text { Research Variable }}$}

Research exogenous variables: brand trust (dov\&doi), and endogenous research variables: customer loyalty

\section{Research Paradigm}

This research is quantitative. The study's final implications are carried out through an inferential statistical approach to prove the truth of the relevance of the research hypothesis empirically (Cooper \& Emory, 1995).

\section{$\underline{\text { Research Model }}$}

$y=\alpha+\beta 1 . x 1+\beta 2 . x 2+e$ (multivariate regression)

$\mathrm{y}=$ Customer Loyalty Parameters

$a=$ Constant Parameters

$\beta 1, \beta 2=$ Regression Parameters $(\beta)$

$x 1=$ Dimension of Viability parameter

x2 $=$ Dimesion of Intentionality parameter

$\mathrm{e}=$ External Parameters Outside the Model

\section{RESULT}

Table 1

Regression Analysis

\begin{tabular}{|c|c|c|c|c|c|}
\hline \multirow[t]{2}{*}{ Model } & \multicolumn{2}{|c|}{$\begin{array}{c}\text { Unstandardized } \\
\text { Coefficients }\end{array}$} & \multirow{2}{*}{$\begin{array}{c}\begin{array}{c}\text { Standardized } \\
\text { Coefficients }\end{array} \\
\text { Beta } \\
\end{array}$} & \multirow[t]{2}{*}{$\mathrm{t}$} & \multirow[t]{2}{*}{ Sig. } \\
\hline & $\mathrm{B}$ & Std. Error & & & \\
\hline $\begin{array}{ll}1 & \text { (Constant } \\
& \text { ) }\end{array}$ & 2.313 & .749 & & 3.087 & .004 \\
\hline Dov & .633 & .113 & .618 & 5.601 & .000 \\
\hline Doi & -.268 & .108 & -.273 & -2.478 & .018 \\
\hline
\end{tabular}

The regression analysis in Table 2 above explains that the dimension of viability (dov) has a positive effect on customer loyalty with the support of pvalue (.000 <from prob std .050). This means that changes in the variation in customer loyalty observations' parameter values can be explained directly in one direction through changes in the variation in the dimension of a viability parameter value of $(63.3 \%)$. Where now the price of pertalite fuel being traded by Pertamina is in the range of $\mathrm{Rp} .7,650$ per liter, the price difference is Rp. 1350 per liter with the price of premium fuel, the Kulon warriors do not feel heavy over the difference in the price of pertalite compared to the price.
Premium because the local people around the Kulon warrior, Mojokerto, believe that pertalite fuel quality is better than premium. Because pertalite energy has a high enough octane content, it can oxidize the combustion more completely and can optimize the performance of the vehicle engine. The residual content of pertalite fuel has lower lead and iron levels, which reduces the waste of motor vehicle engine fuel and is more efficient and cleaner for pollutant residues.

Based on these facts, regular customers at the PERTAMINA depot in the army area think that pertalite fuel has high economic benefits because pertalite fuel does not contain manganese and lead 
elements, which can damage motor vehicle engines with high combustion octane power. Strongly supports the process of fuel efficiency in motorized vehicles, both in the 2 or 4 stroke engine category today. The strong motivational drive for the pertalite fuel customers has triggered the formation of these customer values (especially in the Kulon warrior area, Mojokerto) so that it has a positive impact on these customers to continue to exist consuming pertalite gasoline continuously, until now, even though they have the price difference is quite large (Rp. 1,200 per liter) compared to the current premium price of Rp. 6,450, - per liter.

It is explained that the dimension of intentionality hurts customer loyalty with the support of p-value $(.018<$ from prob std .050), where changes in the variation in the value of the customer loyalty observation parameters cannot be explained directly by the difference in the variation in the value of the dimension of intentionality parameter, because other external elements also influence the customer loyalty observation parameters ($26.8 \%)$. The current pertalite customers are worried about the policies of the government in the future, especially the policy of the Jakarta Oil and Gas Department, which regulates the national oil regulation which will proclaim the elimination of pertalite and premium fuel in the general market by maintaining the existence of Pertamax fuel as an alternative to replace it at a price that is Rp. 9,000, -. This negative perception, as a form of embodiment of the dimension of intentionality observation parameters today, especially the anxiety that arises in pertalite regular customers in the Kulon warrior area, Mojokerto, which is far from feeling safe (inversely proportional to the concept of the dimension of intentionality theory) is interpreted as a negative influence (the reverse direction).

This is another external factor outside the intentionality dimension that also influences the existence of factual (real) customer loyalty observation parameters. It is concluded that H1: the truth is accepted, $\mathrm{H} 2$ : the fact is admitted. Where loyalty is a manifestation of consumers' moral deposit to their retailers, in line with the opinion (Autry et al. 2007).

Table 2

Summary Model

\begin{tabular}{|c|c|c|c|c|c|c|}
\hline Model & $\mathrm{R}$ & R Square & $\begin{array}{c}\text { Adjusted R } \\
\text { Square }\end{array}$ & $\begin{array}{l}\text { Std. Error of } \\
\text { the Estimate }\end{array}$ & $\begin{array}{c}\text { R Square } \\
\text { Change }\end{array}$ & $\begin{array}{l}\text { Sig. F } \\
\text { Change }\end{array}$ \\
\hline 1 & $.774^{a}$ & .599 & .579 & .77304 & .599 & .000 \\
\hline
\end{tabular}

The Summary Model in table 2 above explains a reasonably close correlation coefficient between brand trust (dov\&doi) and customer loyalty (77.4\%). It means that the brand trust formed in pertalite customers can shape their loyalty values as regular customers of pertalite fuel at (Depo Pertamina Soldier Kulon), Mojokerto. The fit test model explains that changes in the variation in the value of the customer loyalty observation parameters can be presented directly by the contribution $(+) \&(-)$ of the variation in the value of the DOV \& DOI observation parameter changes.

Where the research model can predict the linearity of the influence between brand equity (dov\&doi) on customer loyalty, it is representative of the research sampling of 43 pertalite regular customer participants who make repeat purchases at the Pertamina Depo (Kulon Soldier Area), on the entire population in its scope, The target object of observation is $(57.9 \%)$, and the remaining (42.1\%) explains 
Picture 2

Histogram

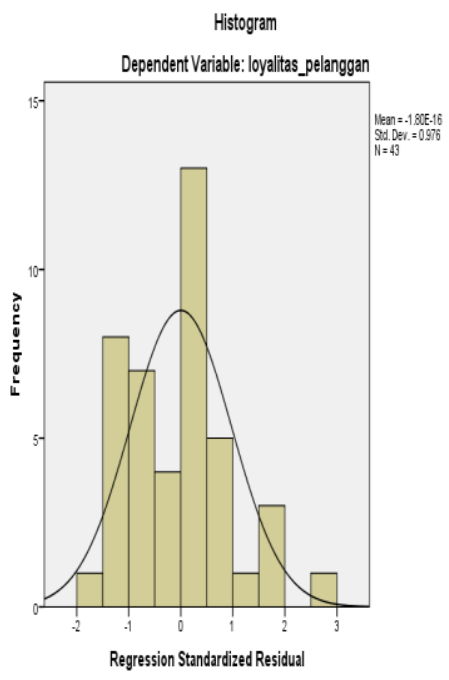

The normality of the curve histogram in Figure 2 indicates that the overall observation data tends to be normally distributed (typical pattern). This can be proven by the normality histogram

curve's progressivity, which tends to curve upward asymmetrically, approaching the abscissa axis of the normality probability frequency peak.

Gambar 3

Scatterplot Model

Scatterplot

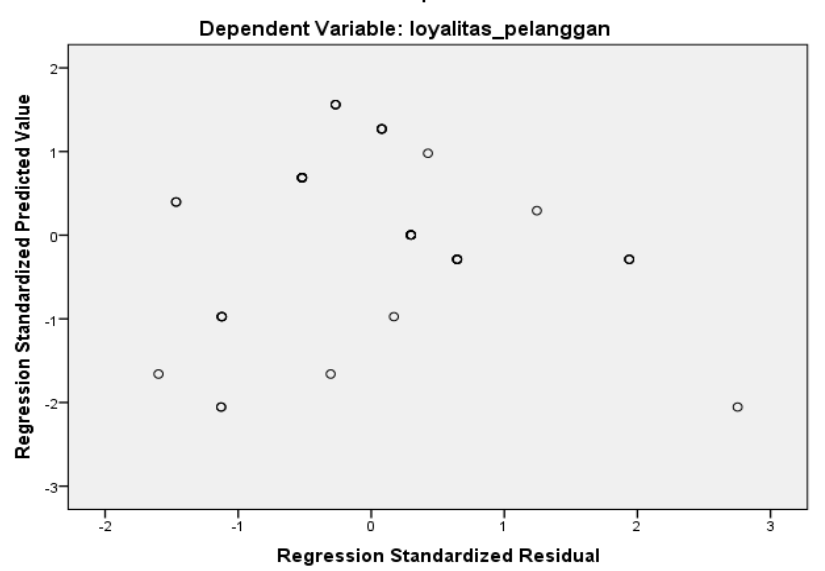

The Scatterplot Model explains that groups of observed object particles tend to be clustered linearly separately from one colony to another to form a separate communality, which means that all observation participants tend to be heterogeneous. This is a process of creating each customer's confidence value, continuing to consume pertalite fuel at the PertaminaKulon soldier depot, or switching purchasing decisions to consume

other pertalite energy outside the Kulon warrior area.

\section{CONCLUSION}

H1 research: accepted the truth, research H2: carried the fact. The fittest model explains that changes in the variation in the value of the customer loyalty observation parameters can be defined directly by the contribution (+) \& (-) 
of the variation in the value of the DOV \& DOI observation parameter changes.

The research model can predict the linearity of brand equity (dov\&doi) on customer loyalty. It represents the research sampling of 43 participants of regular BBM pertalite customers who repurchase fuel Pertamina Depo (Kulon Soldier area) on the entire population. In the scope of the target object of observation (57.9\%), the remaining $(42.1 \%)$ explained the effect indirectly through other external parameters outside the model.

\section{LIMITATIONS}

This study only focuses on the implications of the influence of brand equity on customer loyalty. Further research should develop a research discourse pattern by formulating the brand equity observation parameter as the exogenous observation parameter and ewom as the endogenous observation parameter. Where e-marketing functions as a mediating observation parameter. To mediate the implications of brand equity's direct effect on e-wom through a seminal analysis approach (structural equation modeling), the research analysis model is optimally relevant.

\section{REFERENCE}

Arjun Chaudhuri and Morris B. Holbrook. (2001) The Chain of Effects from Brand Trust and Brand Affect to Brand Performance: The Role of Brand Loyalty.Source: Journal of Marketing,Vol. 65, No. 2, pp. 81-93. American Marketing Association.

AM Prud'homme, KK Boyer, GTM Hult. (2007) An analysis of operations oriented drivers of customer loyalty for two service channels, Direct Marketing: An International Journal. Batubara, Muhammad Fauzan \& Nasionalita, Kharisma. (2016). Pengaruh Brand Trust Indi Home Terhadap Loyalitas Pelanggan. Di Kota Bandung. e-Proceeding of Management: Vol.3, No.2.
Cooper, D.R \& CW Emory, 1995. Business Research Methods, 5th Ed Richard D. Irwin, Inc. New York.

Chad Autry, R. Glenn Richey, Lauren Skinner Beitelspacher, (2007).A Multilevel Approach to Retail Management Education: Integrating Customer and Supply Chain Perspectives,.Marketing Education Review 17(2).

Daniel W. Drezner(2006). The Viscosity Of Global Governance: When Is Forum-Shooping Expensive?The Fletcher School Tufts University.

Elena Delgado Baliester,Jose-Luis Munuera-Aleman. (2005). Does brand trust matter to brand equity?Journal of Product \& Brand Management

Ferdian, M. Ruly. (2011). Analisis FaktorFaktor Yang Mempengaruhi Loyalitas Konsumen Pada swalayan Berkah Di Bangsri Jepara. Jurnal Sains Pemasaran Indonesia Vol. X, No. 3.

Frederick Hong-kit Yim.Rolph E. Anderson, Srinivasan Swaminathan. (2013).Customer relationship management: Its dimensions and effect on customer outcomes, Journal of Personal Selling and Sales Management 24(4).

Jill Griffin. (2010).Succes.com Succes Book Summaries, Customer Loyalty: How to Earn It, How to Keep It.

Kotler Philip and Kevin Lane Keller, (2009). Manajemen Pemasaran Jilid 2. Edisi Ketiga, terjemahan Bob Sabran, Jakarta: Penerbit Erlangga.

Kotler Philip and Kevin Lane Keller, (2012). Marketing Management 13. New Jersey: Pearson Prentice Hall Inc.

Lau, G.T., Lee, S.H. (1999). Consumers' Trust in a Brand and the Link to Brand Loyalty. Journal of MarketFocused Management 4, 341-370

Marcel van Birgelen a, Ad de Jong, Ko de Ruyter, (2006).Research note Multichannel service retailing: The effects of channel performance satisfaction 
on behavioral intentions, Journal of Retailing 82 367-377.

María J.BeriainInmaculada

GómezFrancisco C.IbáñezM.

Victoria SarriésAna I.Ordóñez (2009). Chapter 1 - Improvement of the Functional and Healthy Properties of Meat Products.

Nuruni Ika Kustini. (2009).Experiental Marketing, Emotional Branding, And Brand Trust And Their Effect On Loyality On Honda Motor Cycle Product. Journal of Economics, Business and Accountancy Ventura Volume 14, No. 1, April 2011, pages $19-28$

Platomi Ismani, (2008). Pengaruh Citra Merek Pelumas Meditran Pertamina Terhadap Loyalitas Pelanggan.FISIP UI.

Richard L. Oliver,(2010).Chapter Customer Satisfaction, In book: Wiley International Encyclopedia of Marketing.

Turkyilmaz, Ali dan Coskun Ozkan. (2007). Development of customer satisfaction index model: an application to the Turkish mobile phone sector. Industrial Management and Data System, Vol. 107 No. 5 hal. 672-687.

Umar, Husein. (2014). Faktor-faktor yang Mempengaruhi Loyalitas Pelanggan pada Penerbangan Low Cost Carrier. Jurnal Manajemen Transportasi \& Logistik (JMTransLog) - Vol. 01 No. 02, Juli 2014. ISSN 2355-4721. Institut Bisnis dan Informatika Kwik Kian Gie.

Zoe Dimitriades. (2006). Customer satisfaction, loyalty and commitment in service organizations: Some evidence from Greece, Management Research News.

Zoe Dimitriades. (2006). Customer satisfaction, loyalty and commitment in service organizations: Some evidence from Greece, Management Research News. 


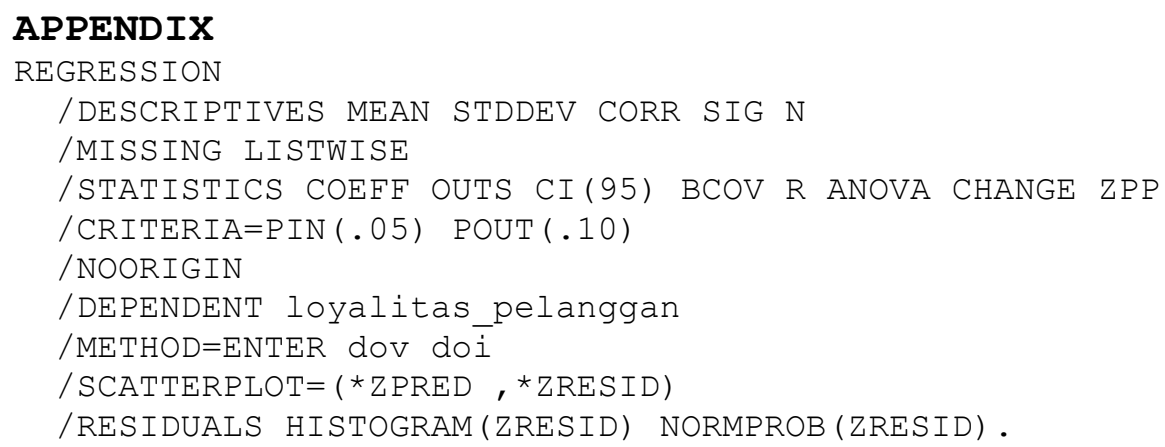

\section{Regression}

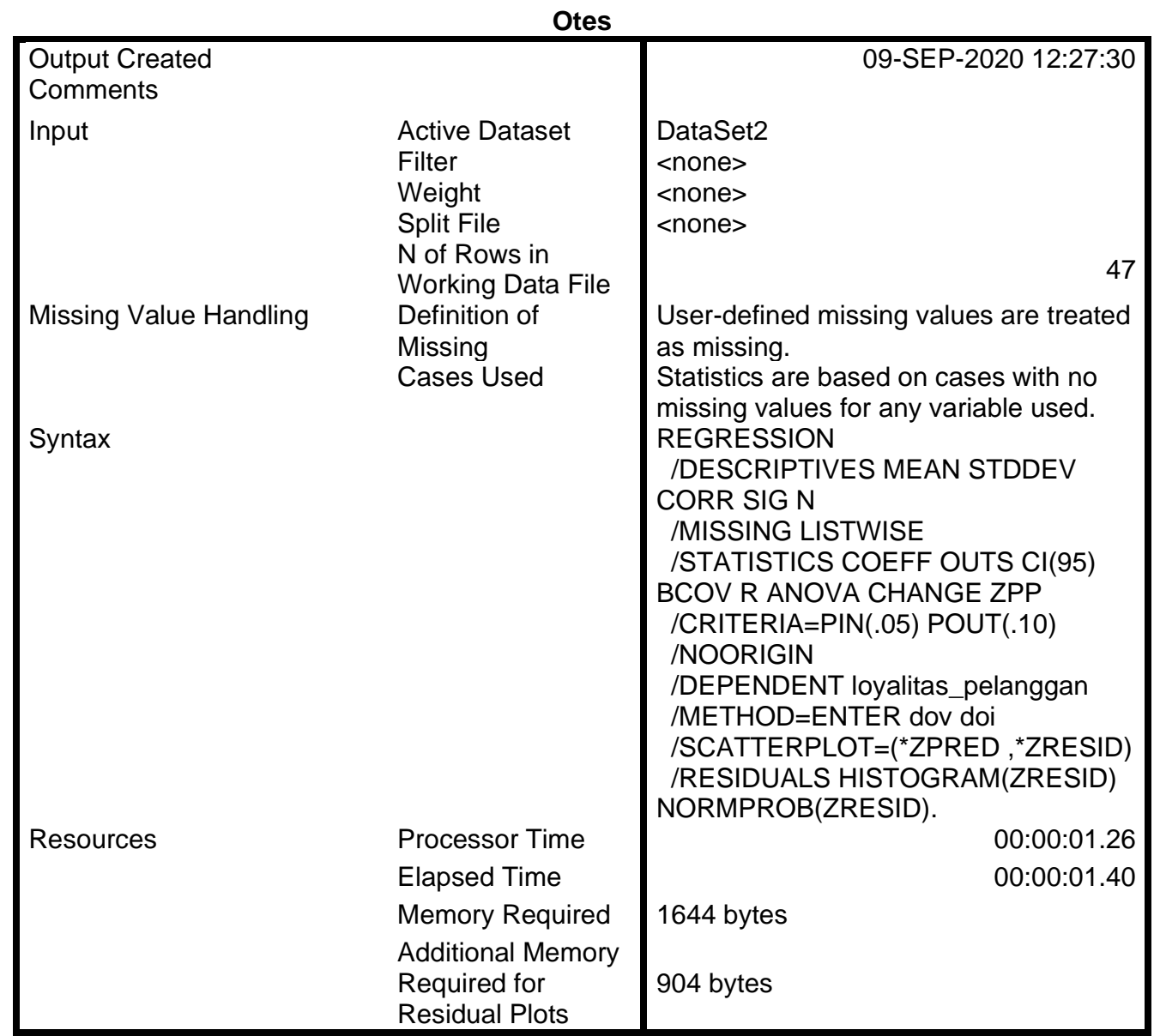




\begin{tabular}{|l|l|l|l|}
\hline Model & Variables Entered & $\begin{array}{l}\text { Variables } \\
\text { Removed }\end{array}$ & \multicolumn{1}{|c|}{ Method } \\
\hline 1 & doi, dov & & Enter \\
\hline
\end{tabular}

a. Dependent Variable: loyalitas_pelanggan

b. All requested variables entered.

Model Summary

\begin{tabular}{|c|c|c|c|c|c|c|c|c|c|}
\hline \multirow[b]{2}{*}{ Model } & \multirow[b]{2}{*}{$\mathrm{R}$} & \multirow[b]{2}{*}{ R Square } & \multirow[b]{2}{*}{$\begin{array}{l}\text { Adjusted R } \\
\text { Square }\end{array}$} & \multirow[b]{2}{*}{$\begin{array}{l}\text { Std. Error of } \\
\text { the Estimate }\end{array}$} & \multicolumn{5}{|c|}{ Change Statistics } \\
\hline & & & & & $\begin{array}{l}\text { R Square } \\
\text { Change }\end{array}$ & \begin{tabular}{c|}
$\mathrm{F}$ \\
Change
\end{tabular} & df1 & $\mathrm{df} 2$ & $\begin{array}{l}\text { Sig. F } \\
\text { Change }\end{array}$ \\
\hline 1 & $.774^{a}$ & .599 & .579 & .77304 & .599 & 29.929 & 2 & 40 & .000 \\
\hline
\end{tabular}

a. Predictors: (Constant), doi, dov

b. Dependent Variable: loyalitas_pelanggan

ANOVA $^{a}$

\begin{tabular}{|ll|r|r|r|r|r|}
\hline Model & & Sum of Squares & df & Mean Square & F & Sig. \\
\hline 1 & Regression & 35.771 & 2 & 17.885 & 29.929 & $.000^{\mathrm{b}}$ \\
& Residual & 23.904 & 40 & .598 & & \\
& Total & 59.674 & 42 & & & \\
\hline
\end{tabular}

a. Dependent Variable: loyalitas_pelanggan

b. Predictors: (Constant), doi, dov

Coefficients $^{a}$

\begin{tabular}{|c|c|c|c|c|c|c|c|c|c|c|c|}
\hline \multirow{2}{*}{\multicolumn{2}{|c|}{ Model }} & \multicolumn{2}{|c|}{$\begin{array}{c}\text { Unstandardized } \\
\text { Coefficients }\end{array}$} & \multirow{2}{*}{$\begin{array}{c}\text { Standardized } \\
\text { Coefficients } \\
\text { Beta }\end{array}$} & \multirow[b]{2}{*}{$\mathrm{T}$} & \multirow[b]{2}{*}{ Sig. } & \multicolumn{2}{|c|}{$\begin{array}{l}95.0 \% \text { Confidence } \\
\text { Interval for B }\end{array}$} & \multicolumn{3}{|c|}{ Correlations } \\
\hline & & B & Std. Error & & & & $\begin{array}{l}\text { Lower } \\
\text { Bound }\end{array}$ & $\begin{array}{l}\text { Upper } \\
\text { Bound }\end{array}$ & $\begin{array}{l}\text { Zero- } \\
\text { order }\end{array}$ & Partial & Part \\
\hline \multirow[t]{3}{*}{1} & (Constant) & 2.313 & .749 & & 3.087 & .004 & .799 & 3.828 & & & \\
\hline & dov & .633 & .113 & .618 & 5.601 & .000 & .404 & .861 & .733 & .663 & .560 \\
\hline & doi & -.268 & .108 & -.273 & -2.478 & .018 & -.487 & -.049 & -.534 & -.365 & -.248 \\
\hline
\end{tabular}

a. Dependent Variable: loyalitas_pelanggan

\section{Charts}



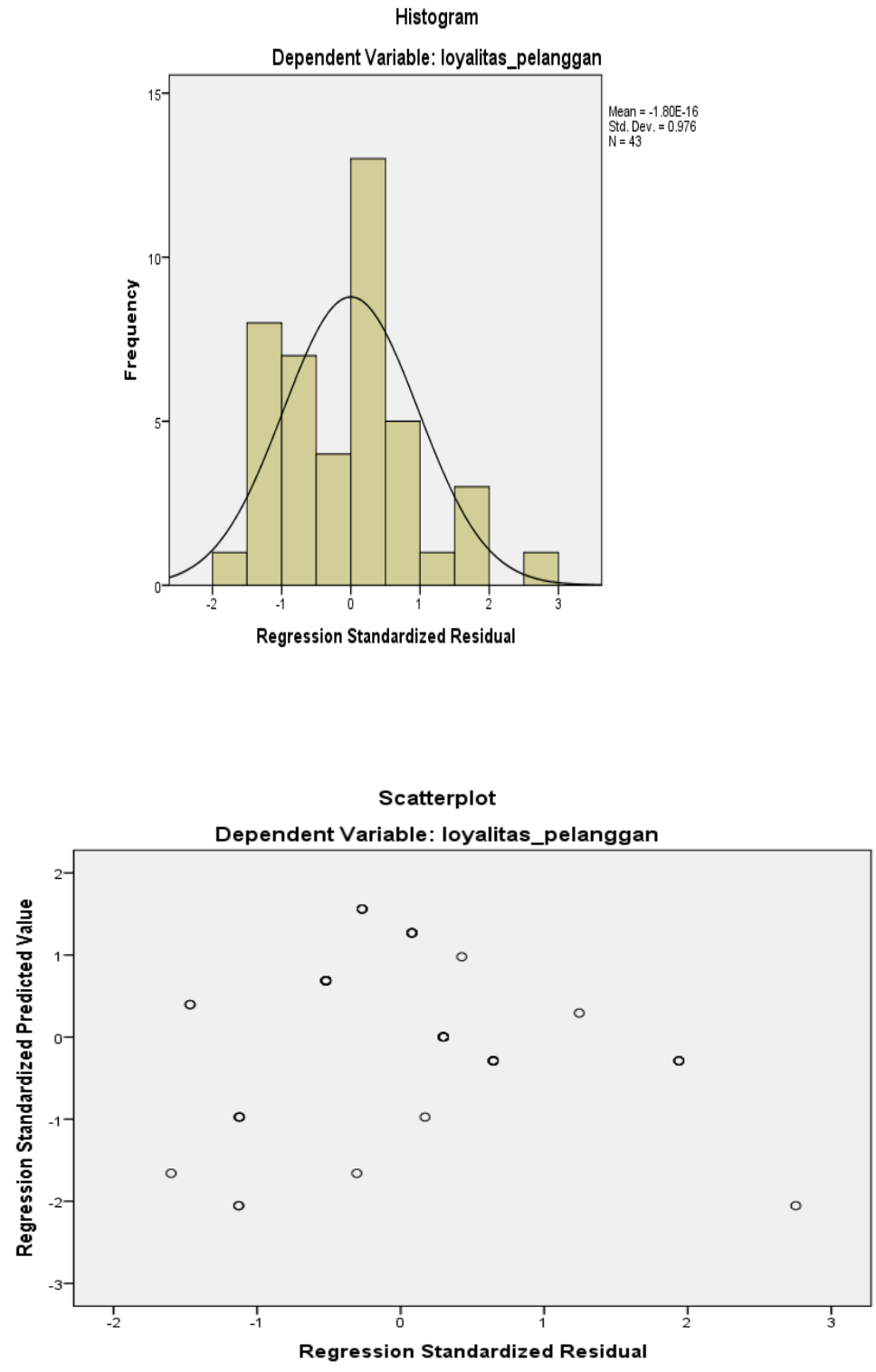

SAVE OUTFILE='E: \DATA TRI 3.sav' /COMPRESSED.

DATASET ACTIVATE DataSet1.

DATASET CLOSE Dataset2. 